\title{
Dealing with flood damages: will prevention, mitigation, and ex post compensation provide for a resilient triangle?
}

\author{
Cathy Suvkens $^{1,2}, \underline{\text { Sally J. Priest }}^{3}, \underline{\text { Willemijn J. van Doorn-Hoekveld }}^{2}, \underline{\text { Thomas Thuillier }}^{4}$ and $^{\text {Marleen van Rijswick }}{ }^{2}$
}

\begin{abstract}
There is a wealth of literature on the design of ex post compensation mechanisms for natural disasters. However, more research needs to be done on the manner in which these mechanisms could steer citizens toward adopting individual-level preventive and protection measures in the face of flood risks. We have provided a comparative legal analysis of the financial compensation mechanisms following floods, be it through insurance, public funds, or a combination of both, with an empirical focus on Belgium, the Netherlands, England, and France. Similarities and differences between the methods in which these compensation mechanisms for flood damages enhance resilience were analyzed. The comparative analysis especially focused on the link between the recovery strategy on the one hand and prevention and mitigation strategies on the other. There is great potential within the recovery strategy for promoting preventive action, for example in terms of discouraging citizens from living in high-risk areas, or encouraging the uptake of mitigation measures, such as adaptive building. However, this large potential has yet to be realized, in part because of insufficient consideration and promotion of these connections within existing legal frameworks. We have made recommendations about how the linkages between strategies can be further improved. These recommendations relate to, among others, the promotion of resilient reinstatement through recovery mechanisms and the removal of legal barriers preventing the establishment of link-inducing measures.
\end{abstract}

Key Words: adaptive building; compensation; flood mitigation; flood risk governance; flood risk prevention; insurance; recovery; resilience

\section{INTRODUCTION}

Solid mechanisms to help society recover from flood events are crucial in any flood risk management (FRM) framework, and financial compensation plays a central role. Flood recovery schemes have already been analyzed in-depth from the perspective of solidarity and accessibility (Faure 2007a, Faure and Bruggeman 2008, Porrini and Schwarze 2014). We present results from the European Union (EU)-funded STAR-FLOOD (Strengthening and redesigning European flood risk practices: towards appropriate and resilient flood risk governance arrangements) project and go a step further to discuss the ways in which the existing ex post compensation schemes in Belgium, the Netherlands, England, and France enhance resilience in combination with existing prevention and mitigation strategies. Our aim is to propose concrete recommendations on how synergies can be improved to provide a coherent FRM approach in which strategies reinforce and complement, rather than undermine, each other. Indeed, earlier comparative research has shown that the linkages between the ex post compensation schemes across the EU and preventing and mitigating flood (risks) have proved to be inadequate (see, e.g., Keskitalo et al. 2014, Lamond and Penning-Rowsell 2014, Penning-Rowsell and Priest 2015, Hudson et al. 2016).

Diversification of FRM strategies, i.e., prevention, defense, mitigation, preparation, and recovery, is recognized as essential for robust and resilient flood governance arrangements (Hegger et al. 2013) and is emphasized by the EU Floods Directive 2007/60/ EC(European Parliament, Council of the European Union 2007). However, it is not sufficient for states to merely adopt additional strategies and measures; to be truly effective, they need to be complementary and aligned. We focus, therefore, on how these different strategies interact and question whether recovery measures, e.g., insurance or public compensation, can encourage action by citizens to increase their resilience and promote adaptation at the individual scale. Flood recovery is a strategy in which the dynamics between public and private actors is highly apparent because the FRM legal realm has an impact, to varying degrees, on insurance schemes for natural disasters. As such, the division of responsibilities and the role of public-private partnerships are critical to the recovery-risk reduction nexus. For example, in countries where private insurance offers the primary route to cover flood risks, the government has various ways that it may facilitate the adequate operation of the insurance scheme vis-à-vis the flood risks, for example by providing a fallback mechanism in case insurance caps have been exceeded (Faure 2007a). We do not aim to make normative judgments regarding the nature of the compensation scheme applicable in the countries an sich but, rather, point out where the vulnerabilities and opportunities for the linkages with risk prevention and mitigation within these systems lie. In this regard, a question also relates to the roles of private parties, i.e., the insurers, and the public authorities in facilitating these linkages between ex post compensation schemes and risk prevention and mitigation.

Two main research questions form the heart of the analysis:

1. How do the frameworks for ex post compensation in Belgium, England, the Netherlands, and France promote risk prevention and mitigation actions to reduce citizens' exposure and vulnerability to floods, and which good practices can be put forward?

2. Which legislative and policy actions can be taken at the national level to facilitate solid linkages between ex post compensation mechanisms and measures to promote flood prevention and mitigation actions?

Before delving into the comparative discussion, we will first clarify the methodological approach we have adopted and the theoretical backbone supporting the analysis.

${ }^{1}$ Institute for Environmental and Energy Law, KU Leuven, ${ }^{2}$ Utrecht Centre for Water, Oceans and Sustainability Law, Utrecht University, ${ }^{3}$ Flood Hazard Research Centre, Middlesex University, ${ }^{4}$ Laboratory for Studies and Researches on Public Action, Université François-Rabelais (Tours) 


\section{METHOD}

An external comparative analysis of the legal and policy frameworks governing ex post flood compensation in Belgium, the Netherlands, France, and England has been undertaken. The value of such a comparison is that it provides an opportunity to identify best practices, as well as barriers to the linking of strategies, and identifies the context in which a measure is, or is not, working. The selected countries offer a range of different approaches to flood recovery, with differing degrees of public and private involvement, implemented within varying legal traditions. As such, they provide a broad basis from which lessons can be drawn and from which widely applicable recommendations can be made. In Belgium and France, mandatory insurance product bundling exists, although the mechanisms are sculpted differently in terms of risk differentiation. Both systems are hybrids, in the sense that both public and private actors play an important role. The schemes applicable in England and the Netherlands are on opposite sides of the flood recovery spectrum, the former being almost exclusively governed by the private insurance industry, and the latter fully governmentally managed. ${ }^{[1]}$

The legal comparative research utilizes a functionalist approach (Graziadei 2003, Siems 2014) whereby analysis starts from a particular issue, in this case postflood compensation, and aims to identify good practices and lessons learned (Smits 2012). Among others, the following considerations constitute the tertium comparationis, which is established by the common denominators of the comparison we have made: the challenges posed by floods, the public-private division of responsibilities conundrum associated with the natural disaster compensation, and the necessity to create solid links between recovery measures taken following a flood and those aimed at minimizing societal exposure to floods. The comparative approach has included the extensive and systematic analysis of both historical and contemporary legal and policy documentation by researchers within each of the countries familiar with the FRM approaches and legal context. To realize a functionalist approach, this analysis has been supplemented by interviews with high-level stakeholders involved in policy development. This has involved, for example, water managers, insurance professionals active in organizations representing the insurance industry, and professionals active in financial institutions involved in product development. Interviewees were selected to provide additional information about the functioning of the recovery approaches in practice, potential future developments, and insight into maximizing the links between FRM strategies. Interviews were, in general, recorded, transcribed, and subsequently analyzed through a systematic coding approach, which was commonly applied to the findings in each country (Hegger et al. 2013). ${ }^{[2]}$

\section{SETTING THE SCENE: RESILIENCE AND THE TRIANGLE}

The main linkages we analyze are those between the strategies of recovery and flood risk prevention and recovery and flood mitigation (Green et al. 2013, Hegger et al. 2013:29). There are two main reasons for this particular delineation of scope. First, we aim to identify how individual actions by citizens can be promoted by the recovery strategy, and the most significant opportunities for these types of actions are situated in the interconnections between recovery, risk prevention, and mitigation (Figure 1). Second, we focus on actions that can be taken before or after a flood has taken place, which is why the flood preparation strategy, for instance crisis management, is not a core subject of analysis.

Flood risk prevention, hereinafter also referred to as the "prevention strategy," relates to all measures taken to keep people away from the water, i.e., through spatial planning and development control. The mitigation strategy, on the other hand, aims at resisting or accommodating water through measures such as adaptive building and/or flood proofing at the individual scale (Alexander et al. 2013). In this respect, individual measures that might be considered as falling into the category of flood defense, such as property-level resistance measures, form part of the mitigation strategy in the context of our research.

For us, the concept of resilience is paramount. Social-ecological resilience has been referred to as the ability of a certain mechanism to develop further and reorganize following a disturbance, in casu floods (Folke et al. 2005). Adaptability is thus a key concept in achieving resilience and is recognized both within the context of environmental policy sciences (Dietz et al. 2003, Folke et al. 2005, Nelson et al. 2008) and legal studies of environmental governance (e.g., Cosens 2013, Garmestani and Benson 2013, Chaffin et al. 2014). Furthermore, one of the indicators related to resilience of a social-ecological system is that there is sufficient coordination across different scales and between different aspects of decision making (Folke et al. 2005, Cosens 2010, Reed et al. 2010). As such, for managing flood risk this means effective coordination between the implemented FRM strategies (Cosens 2010). The linkage between prevention or individual mitigation and recovery is thus an important factor in achieving resilience of a social-ecological system. A well-developed insurance mechanism can play an important role in FRM because it may provide stimuli for people to steer clear of flood prone areas or take adaptive measures, while facilitating economic recovery following flooding (Kunreuther 1996, Crichton 2008), thus increasing adaptability of the system. Insurance schemes that are not properly designed can have the opposite effect and negatively impact society's capacity to cope with future flood risk (Surminski et al. 2015). For example, it has been argued that universal insurance coverage could encourage further development in flood risk areas (Pryce 2011), and the availability of insurance, without conditions, could discourage proactive risk reduction because it acts as a buffer for recovering from flood events. One of the most apparent barriers to the promotion of flood risk reduction by insurance schemes is the absence of risk-reflective premiums (Blanchard-Boehm et al. 2001, Priest 2014). Also, pursuant to what Kunreuther (2008) has referred to as "the natural disaster syndrome," stakeholders are not inclined to voluntarily take disaster risk reduction measures because of notions of risk denial or displacement. The particular nature of ex post compensation for floods thus requires a wellthought-through synergy between and within several axes, namely, (1) the promulgation of rules and regulations issued by the state and reliance on the private market; (2) several sectors, such as spatial planning, water management, and insurance; and (3) the responsibilities of private citizens and compensatory bodies such as the state and insurers.

Our goal is to evaluate whether the respective triangles in the selected countries enhance flood resilience and provide recommendations to increase this resilience. Key criteria for this 
Fig. 1. The linkage between flood risk management strategies.

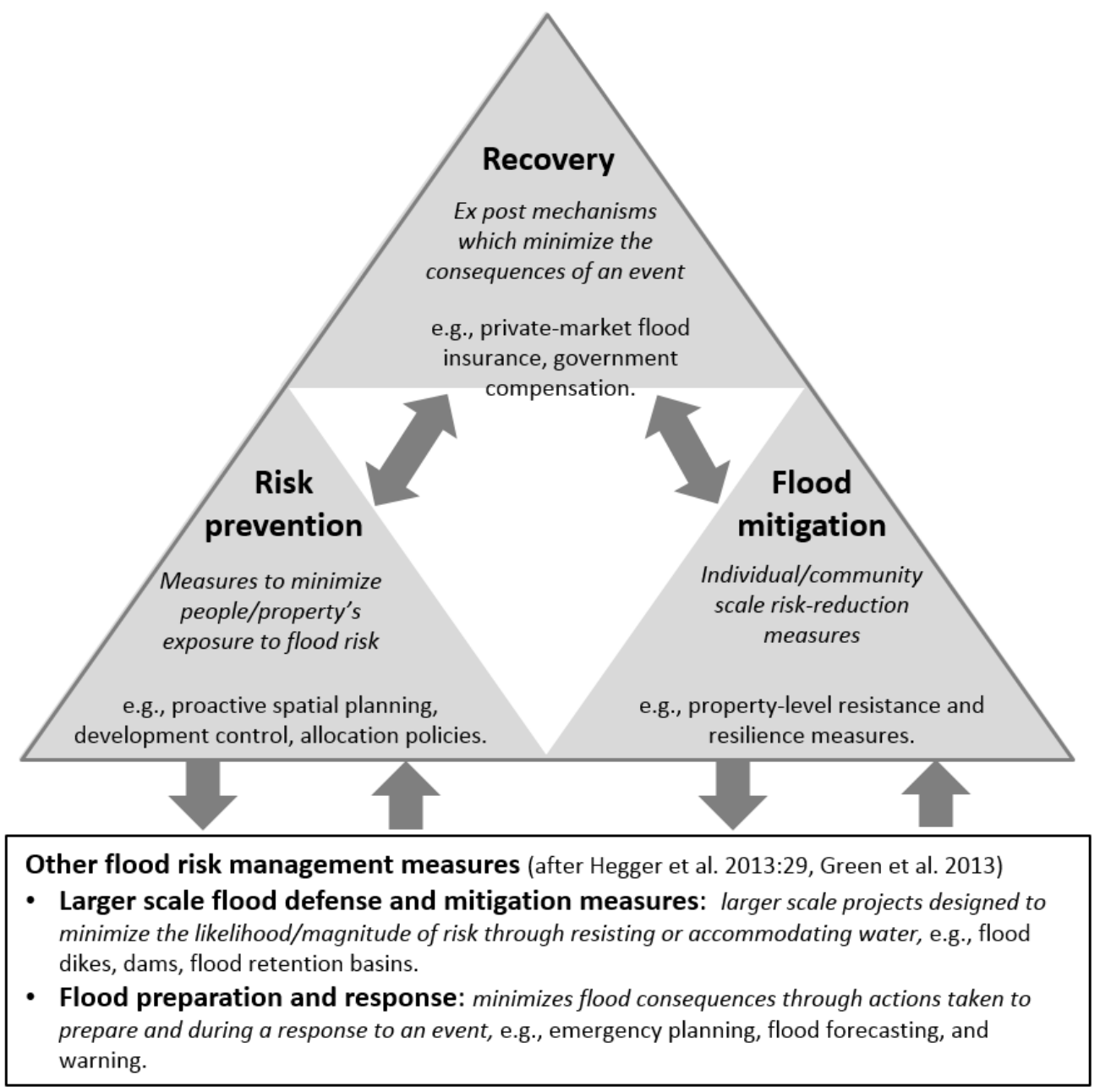

evaluation are summarized in Table 1. Existing research (e.g., Michel-Kerjan 2001, Faure 2007b, Botzen and Van Den Bergh 2008, Mehlhorn and Hausmann 2012, Porrini and Schwarze 2014, Priest 2014) provides some examples of indicators, which are herein used to identify and evaluate the current links between recovery and other FRM strategies. Analysis then identifies the extent to which these links are present and effective in practice. Other potential and realized linkages have also emerged from the empirical research conducted.

Ex post compensation for floods in Belgium, England, the Netherlands, and France

Table 2 provides an overview of the basic characteristics of the existing ex post compensation mechanisms in the selected countries. The first characteristic relates to the question of involvement of public and private parties. The Netherlands has both a governmental compensation scheme, the Calamities Compensation Act (CCA; Act of 25 May 1998 on the Regulations on Contribution for the Damage and the Costs in Case of Freshwater Flooding, Earthquakes or Other Catastrophes and Large Accidents, Stert. 11 June 1998), and private flood insurance, the Neerlandse. The public compensation approach is more significant, and further analysis presented will mainly concentrate on this mechanism. For France, Belgium, and England, ex post compensation is dominated by market-based insurance mechanisms with varying degrees of involvement of state actors. The second characteristic relates to the question of whether, in the context of insurance, flood risk coverage is bundled with other insurance policies. In the French, Belgian, and English schemes, this coverage for flood risks is bundled with other perils, whereas in the Netherlands, flood risk coverage is separate from other insurance policies. The third characteristic pertains to the degree of solidarity between citizens in the context of ex post compensation, namely, the question of whether all citizens contribute to the compensation mechanism or only, for example, people at risk. In France and the Netherlands, solidarity is very high for different reasons explained subsequently. Finally, the question arises as to whether the countries have adopted a risk differentiation approach, as is the case in Belgium for example.

The Belgian and French schemes are quite similar because they both involve the automatic and compulsory inclusion of flood coverage in voluntary first-party property insurance policies (Faure and Bruggeman 2008) and have a public fallback 
Table 1. Main criteria for evaluating the resilience of the triangle.

\begin{tabular}{|c|c|}
\hline Main Criteria & Example Indicators \\
\hline $\begin{array}{l}\text { The ex post compensation mechanism facilitates "keeping people away } \\
\text { from the water" in a structural manner. }\end{array}$ & $\begin{array}{l}\text { Availability of compensation, e.g., exclusion of high-risk properties from } \\
\text { recovery schemes and exclusion of new buildings; affordability as a } \\
\text { deterrent, e.g., risk-related premiums and risk-related deductibles }\end{array}$ \\
\hline $\begin{array}{l}\text { The mechanism incentivizes individuals to take adaptive building measures } \\
\text { and retrofitting in a structural manner. }\end{array}$ & Premium reductions for uptake of individual-scale defense or mitigation \\
\hline $\begin{array}{l}\text { Systematic coordination and cooperation between relevant public and } \\
\text { private stakeholders }\end{array}$ & Structural information exchange platform, shared cartography \\
\hline Link between water and flood risk management and ex post compensation & $\begin{array}{l}\text { Coordinated tools for identifying high-risk zones, implications for both ex } \\
\text { post compensation and spatial planning }\end{array}$ \\
\hline $\begin{array}{l}\text { Awareness raising is taking place on a structural basis about the existence } \\
\text { of flood risks and their implications. }\end{array}$ & Compulsory informing requirements \\
\hline Legal effectiveness & Legal provisions are adequately followed up and enforced. \\
\hline
\end{tabular}

mechanism. Up until the entry into force on 1 March 2007 of the 2005 reform of the Insurance Act, ex post compensation in Belgium was fully sponsored through public funding, i.e., the Natural Disasters Act of 1976 (Act of 12 July 1976 on the Repair of Certain Damage Caused to Private Goods by Natural Disasters, Belgian Official Journal, 13 August 1976). Since then, flood coverage has been automatically included in the simple fire policy for Belgian citizens, i.e., the Insurance Act of 2014. The Belgian insurance market thus upholds mandatory product bundling. Fire policies are not obligatory but are taken up by $90 \%-95 \%$ of the population (Colle 2006). Furthermore, fire policy coverage is generally a condition for obtaining a mortgage, which in part explains the high penetration. The previously solo operating mechanism, the Disaster Fund, is retained and acts as a fallback mechanism for damages to goods that are not covered by the simple fire insurance coverage, e.g., for goods that are not considered as simple risks (Bruggeman 2010). The Disaster Fund also intervenes if the limits of the insurers have been exceeded, because the amount that insurers are expected to pay out for a particular event is capped (Natural Disasters Act of 1976, article 34). Following the Sixth State Reform, the Disaster Fund was transferred from the federal level to the regional level (Special Act of 6 January 2014 on the Sixth State Reform, Belgian Official Journal, 31 January 2014), and insurance-related issues remained at the federal level. For floods that have occurred before 1 July 2014, the federal mechanism of the Disaster Fund applies, and for disasters after that date, the mechanisms applicable in the three regions, i.e., Flanders, Wallonia, and the Brussels-Capital Region, will apply. However, the system is relatively untested, and there still remains a large degree of uncertainty about the details of this transfer in relation to many issues including the competences for declaring a flood as a natural disaster and the financial means to provide compensation. The activation of the insurance mechanisms in Belgium for simple risks does not depend on the acknowledgment of the flood event as a natural disaster. For floods that occurred at the time when ex post compensation was still exclusively effectuated through public funding, these declarations through royal decree were important. Still today, even though compensation via insurance does not depend on a state declaration, compensation provided through the Disaster Fund does.

The Belgian ex post compensation system is based on the French system, albeit with a different approach to solidarity. In both countries, solidarity is high because of the automatic inclusion of flood risks within fire policies. The "compulsory" nature of these insurance schemes can be highlighted as an important aid to recovery (Van den Bergh and Faure 2006, Lamond and PenningRowsell 2014). However, the difference in the solidarity approach adopted by the respective countries lies in the differentiation in the Belgian scheme between buildings located in high-risk zones and those in lower risk areas. In comparison, in France, all citizens pay a single rate, with the amount calculated as a proportion of the base policy, set forth through ministerial decree, regardless of their exposure to flood risk.

In France, for a long time, damages caused by natural disasters such as floods, earthquakes, or droughts were not compensated though insurance contracts because of their recurring and unpredictable character. Public authorities granted public subsidies on a case-by-case basis. Following the disastrous 1981 floods, in 1982 the French Parliament adopted a law creating a public-private partnership between insurance companies and the state to compensate damages resulting from natural disasters: the Catastrophes Naturelles (CAT-NAT) regime. Flood risks are covered in first-party insurance policies for buildings and movable property (Bruggeman 2010). Twelve percent of the proceeds of the insurance premiums are then redistributed between insurance companies and the Central Reinsurance Company (CCR), a reinsurance company fully owned by the state. Insurers realize they need to compensate material damages following a natural disaster event, regardless of the amount to be paid; therefore, they purchase reinsurance to cover their own risk exposure, either through the CCR or a private reinsurer. The advantage of the $\mathrm{CCR}$ is that it offers unlimited coverage because of the guarantee of the French state. In contrast to the Belgian scheme, there is no limit to the governmental fallback mechanism. Recently, this characteristic has been brought before the French Constitutional Council through a priority preliminary ruling on constitutionality to test if this unlimited coverage creates a competitive advantage. On 27 September 2013, the Constitutional Council considered that this advantage does not constitute a breach of the freedom of entrepreneurship or the equality principle, both of which are protected by the French constitution. This decision is a clear illustration of the primacy of public over private interests. Finally, in France, the compensation of damages following floods by insurers depends on the acknowledgment of the flood as a natural disaster through an administrative decision. 
Table 2. Overview of ex post compensation mechanisms for floods in the selected countries.

\begin{tabular}{|c|c|c|c|c|c|}
\hline \multirow{2}{*}{$\begin{array}{l}\text { Type of } \\
\text { Compensation }\end{array}$} & \multirow[t]{2}{*}{ Belgium } & \multirow[t]{2}{*}{ France } & \multirow[t]{2}{*}{ England: Flood Re } & \multicolumn{2}{|c|}{ The Netherlands } \\
\hline & & & & $\mathrm{CCA}$ & Neerlandse \\
\hline Public-private divide & $\begin{array}{l}\text { Both: } \\
\text { Private insurance } \\
\text { mechanism with public } \\
\text { fallback mechanism + set } \\
\text { of regulations related to } \\
\text { risk differentiation, etc. }\end{array}$ & $\begin{array}{l}\text { Both: } \\
\text { Private insurance } \\
\text { mechanism with public } \\
\text { fallback mechanism + set of } \\
\text { regulations related to } \\
\text { insurance fees, etc. }\end{array}$ & $\begin{array}{l}\text { Mainly private: } \\
\text { Private insurance mechanism } \\
\text { with formal cross- } \\
\text { subsidization via a pooled } \\
\text { system }\end{array}$ & Public & Private \\
\hline $\begin{array}{l}\text { Bundled/unbundled } \\
\text { (level of } \\
\text { compulsion) }\end{array}$ & $\begin{array}{l}\text { Bundled: } \\
\text { Mandatory product } \\
\text { bundling but within a } \\
\text { voluntary insurance policy } \\
\text { (fire) }\end{array}$ & $\begin{array}{l}\text { Bundled: } \\
\text { Mandatory product } \\
\text { bundling but within a } \\
\text { voluntary insurance policy } \\
\text { (fire) }\end{array}$ & $\begin{array}{l}\text { Bundled: } \\
\text { Bundled with homeowner } \\
\text { insurance (standard peril) }\end{array}$ & N/A & $\begin{array}{l}\text { Unbundled and } \\
\text { optional }\end{array}$ \\
\hline Degree of solidarity & $\begin{array}{l}\text { High: } \\
\text { Because flood risk } \\
\text { coverage is included in fire } \\
\text { insurance, } 90 \%-95 \% \text { of the } \\
\text { citizens pay, regardless of } \\
\text { whether a person lives on } \\
\text { the } 40 \text { th floor of an } \\
\text { apartment building or not. }\end{array}$ & $\begin{array}{l}\text { Very high: } \\
\text { All citizens pay a single rate, } \\
\text { regardless of their exposure } \\
\text { to flood risks. }\end{array}$ & $\begin{array}{l}\text { High: } \\
\text { However, only between the } \\
\text { insured }\end{array}$ & $\begin{array}{c}\text { Very high: } \\
\text { All citizens } \\
\text { contribute through } \\
\text { taxes. }\end{array}$ & $\begin{array}{c}\text { Low: } \\
\text { Completely optional }\end{array}$ \\
\hline Risk differentiation & $\begin{array}{l}\text { Yes: } \\
\text { No ceiling on insurance fee } \\
+ \text { possibility for insurers to } \\
\text { refuse coverage for those } \\
\text { buildings built in a flood } \\
\text { prone area after } 23 \\
\text { September } 2008\end{array}$ & $\begin{array}{l}\text { Not explicitly: } \\
\text { Considering the application } \\
\text { of the single rate, regardless } \\
\text { of the exposure to flood } \\
\text { risks }\end{array}$ & $\begin{array}{l}\text { Yes: } \\
\text { Flood Re aims to gradually } \\
\text { increase premiums. }\end{array}$ & $\begin{array}{l}\text { Outside the dike } \\
\text { area }\end{array}$ & Yes \\
\hline
\end{tabular}

Whereas Belgium and France have varying degrees of public intervention in the existing insurance schemes, the English scheme has been more private in nature. Flood insurance has been available as part of a standard household policy for many decades, and the system of its provision has been relatively stable (Penning-Rowsell and Priest 2015). In part, this stability was created by an informal agreement, the "Gentleman's Agreement" (BIA/FOC 1961), between members of the insurance industry and the government, in which the universality of insurance provision was guaranteed. In more recent years, this arrangement was replaced by a series of further agreements, the Statement of Principles (e.g., ABI 2008), in which the UK government committed to strengthening spatial planning and constructing flood defenses in return for continued universal coverage. There are multiple reasons for the need to move from a system based on informal agreements toward a new approach to flood insurance, including concerns about maintaining the affordability of insurance, changes to the marketplace and the entrance of new insurers, industry concerns about repeated losses, and the general consideration by the insurance industry that government has not acted sufficiently to prevent inappropriate development and mitigate flood risks (Huber 2004, Lamond et al. 2009, O’Neill and O'Neill 2012, Ball et al. 2013, Surminski and Eldridge 2014, Penning-Rowsell and Priest 2015).

Introduced in April 2016, the Flood Reinsurance Scheme (Flood $\mathrm{Re})$ represents the largest change to insurance provision in
England in almost 100 years (Penning-Rowsell and Priest 2015). The introduction of Flood Re aims to maintain the affordability and availability of flood insurance to domestic properties through the pooling of higher risks. The new approach, legislated via the Water Act of 2014 (chapter 21, part 4) and additional secondary legislation, The Flood Reinsurance (Scheme and Scheme Administrator Designation) Regulations 2015 (Statutory Instrument No. 1875), establishes a not-for-profit reinsurance fund from which private insurance companies will be allowed to draw to settle claims for those properties that they have chosen to cede to the scheme. Flood Re permits a graduated and banded premium cap to be placed on domestic properties and, as such, subsidizes the premium costs of high-risk households (Defra 2013). The Flood Re pool will be fully managed by the insurance industry, although regulated by the government, and is funded through premiums of those properties ceded into the scheme and a levy payable by all private insurers providing domestic insurance policies. The amount each insurer contributes is based on the insurer's market share. It has been estimated that this levy for each of the first 5 years will be on the order of $£ 180$ million (Defra 2013). Those insurance professionals interviewed suggested that this levy will likely be passed on to consumers, and therefore, all who have a household insurance policy will contribute and crosssubsidize those at high flood risk, albeit by differing amounts. The degree of solidarity in England is thus relatively high, with insurance penetration at $\sim 70 \%$; however, it exists only between those insured because there is no other formalized compensation scheme. 
Whereas Belgium, France, and England rely on the private insurance market for the bulk of compensation offered for damages resulting from floods, the Netherlands adopts a different approach. Analysis of flood risk policy shows that the recovery strategy in the Netherlands is the least developed in comparison to the other FRM strategies, a view confirmed by interviews. This is because the focus is based on protection from floods using defense infrastructure. This can in part be explained by geographic circumstances because the Netherlands is a low-lying delta with large flood prone areas in which most of the population lives and works. Thus, should a flood occur, the extent of damage would be unimaginably high, which is why after the 1953 floods, insurance companies declared flood risks uninsurable. The strong focus on protection strategies implies that the recovery scheme functions as a measure of last resort. In this circumstance, the CCA may be enacted. This is an exclusive governmental competence; water management in the Netherlands is the responsibility of the government, with water authorities having a constitutional duty to keep people who live in dike-protected areas safe from harm. If the CCA is triggered, a specific regulation comes into force, which is created for the specific situation. Individuals may request compensation for part of their loss. However, the CCA has only been declared applicable five times since 1998. The recovery compensation regime is based on the principle of solidarity; it is funded through general means, with all Dutch citizens contributing (Explanatory Memorandum to the CCA, Kamerstukken II, 25 159, no. 3). The CCA is only applicable in cases in which flooding has been formally declared to be a disaster, so for smaller floods, no compensation will be provided (Hartlief 2014). The CCA mechanism has been criticized for being ad hoc and for the lack of clear and transparent provisions regarding the compensation of victims (Bruggeman 2011).

In the 1950s, the Dutch insurers made a binding agreement in which they agreed not to cover damage as a result of flooding. Even though this agreement can be considered as a prohibited cartel, the insurers continue refusing coverage, without a substantial contribution of the state (Hartlief 2014). Despite this, in 2011, a pilot insurance policy was launched, the Neerlandse, with the goal of making flood risks insurable. Not all types of flooding are covered by the Neerlandse; e.g., damage caused by pluvial flooding and by groundwater is excluded. The Neerlandse insurance policy is only purchased by a very small percentage of the population, and from interviews with the Association of Dutch Insurers in 2014, it became clear that insurers are hesitant to give detailed information about the costs because these depend on individual circumstances.

\section{COMPARISON OF THE LINKAGE BETWEEN RECOVERY, RISK PREVENTION, AND MITIGATION IN THE SELECTED COUNTRIES}

For each of the compared countries, we examine in more detail the degree to which there are links between recovery and the strategies of prevention and mitigation embedded within the approach.

\section{Recovery and flood risk prevention}

Three ex post compensation mechanisms provide for risk differentiation and prevention promoting actions, albeit to varying degrees. The Dutch situation differs because it has no widespread insurance system, and the CCA provides for compensation only in specific circumstances.

The Belgian compensation scheme contains built-in awarenessraising and risk differentiation mechanisms. All buildings constructed 18 months from the date of publication of the Royal Decree of 23 September 2008 in delineated high-risk areas do not benefit from the maximum insurance tariffs set forth by the public Tariff Office (2014 Insurance Act [Act of 4 April 2014 Related to Insurances, Belgian Official Journal, 30 April 2014], article 129 $\S 3$; 2007 Royal Decree Risk Zones [Royal Decree of 28 February 2007 Related to the Delineation of the Risk Zones within the Meaning of Article 68-7 of the Act of 25 June 1992 on the Land Insurance Contract]). This signals an effort by legislators to discourage citizens from constructing properties in flood prone areas, with a perspective that there should be limits to how far solidarity should stretch. Consequently, in these areas, the cost of premiums is at the discretion of insurers, who are not obliged to provide coverage. Thus, the unavailability of insurance is a potential deterrent to development. Similarly, the Disaster Fund will not intervene for damage to buildings located in these highrisk areas. The transfer of the Disaster Fund to the regions is an important evolution because it implies a potential step toward integrated FRM. A substantial part of the recovery strategy now pertains to the same government that is responsible for flood prevention and, in particular, proactive spatial planning.

In comparison to the Belgian scheme, the solidarity principle is even more vital to the French mechanism (Insurance Act of 1982). Whereas the Belgian scheme explicitly differentiates between buildings located in high-risk zones and those that are not, in France, all citizens pay a single rate, regardless of their exposure to the flood risks. Such an approach can be explained mainly by the importance of the égalité principle in France, namely, equality vis-à-vis government encumbrances. Each person insured is obligated to pay an additional charge of $12 \%$ (Decree of 4 March 2009). The payment of this charge is obligatory because, as previously mentioned, natural disasters are automatically covered by French home and vehicle insurance policies. The French scheme is thus at the outset inherently flawed in terms of the linkage between the recovery and prevention strategies. The determination of this fixed rate by the government prevents insurance companies from adopting a premium rate calculated in proportion to risk exposure. However, certain measures included in the CAT-NAT scheme do have an impact on prevention. The link between the flood risk prevention and recovery strategies is most apparent with respect to financial resources. Indeed, $12 \%$ of insurance proceeds are distributed to the Barnier Fund, which finances the prevention of major natural hazards including prevention, defense, mitigation, and preparation actions. The rationale behind this redistribution of insurance proceeds is that such actions decrease the exposure of insurers (Cans 2014). For instance, the Barnier Fund finances $40 \%$ of surveys and risk reduction work required by the community-based plans for the prevention of natural risks (PPRI) and 50\% of the studies carried out prior to dynamic flood retention work.

Besides financial resources, the CAT-NAT also facilitates other links with the prevention strategy. The insurer can amend the deductible for buildings not covered by a PPRI. The deductible can be doubled if a property receives compensation three times, 
tripled from the fourth time, and quadrupled from the fifth time compensation is provided (Insurance Code, article A.125-1). The main aim of this modulation system created in 2003 (Ministerial Order No. 2003-08-04 of 29 August 2003 Amending the Article A.125-1 of the Insurance Code) is to incentivize citizens to lobby the state to adopt a PPRI to avoid any increase of the deductible (Moréteau 2007). Despite good intentions, reports have shown that the incentivizing effect is quite low (Hourdeau-Bodin 2015). In insurance law, deductibles are used to encourage the insured to take preventive actions, but there is no direct link between the state responsible for the adoption of a PPRI and the insured. Hence, this system is considered as unfair and not incentivizing (Collombat 2012). Another way of linking insurance and prevention is for an insurer to legally refuse to cover flood risk for new properties built in areas designated as "unbuildable" by a PPRI, i.e., if a property is constructed in violation of the plan (Insurance Code, article L.125-6). Additionally, insurance companies can be exceptionally relieved from their obligation to insure goods and activities situated in a risk area if the insured did not comply with any prevention and mitigation measures contained in the applicable PPRI. To this end, the insurer should notify this exemption of coverage to the insured and needs to gain approval from the Tariff Office (Insurance Code, article R.250-3). In theory, these measures could lead to higher levels of awareness of flood risks and stronger incentives to take prevention and mitigation measures. However, many of these options for deductible modulation or exclusion are not being used by insurers (Collombat 2012, Poussin et al. 2013, Hourdeau-Bodin 2015). These legal options miss their effect, mainly because insurers tend to consider that it is not up to them to punish their insured clients (interview, R. Nussbaum, head of French insurance trade associations, 2014). Furthermore, insurance companies that may want to use these rights must be prepared for potential reputation damage. A 2012 legislative reform proposed to transform these options into requirements (Impact Study Reform Insurance Act of 2012), but Parliament has not yet adopted this reform.

In line with the private nature of the English insurance scheme, unlike in France and partly in Belgium, the setting of premiums is at the discretion of each insurance company. In England, under the pre-Flood Re system and the associated Statement of Principles (ABI 2008), the agreement between an insurance company and the government only pertained to maintaining universal coverage and had no discussion of premium pricing. However, this did not guarantee the affordability of insurance. Even in the original "Gentleman's Agreement" in 1961 (BIA/FOC 1961), insurance companies were free to set premiums to reflect risk and could insist that households in higher risk zones pay more for their insurance than those at lower, or no, risk. Despite this, although there was an indication that those who had been flooded were being charged increased renewal premiums (Cobbing and Miller 2012), in general the market showed a level of distortion, with those at higher risk not paying significantly more than those at lower flood risk (ABI 2010). Flood Re aims to eliminate this distortion by gradually increasing the risk reflectiveness of premiums over the coming years and reducing this crosssubsidization. Transitioning to risk-reflective premiums is recognized as challenging (Hudson et al. 2016), and Flood Re is a transition scheme to provide time (20-25 years) for property owners to take action to reduce risk and, consequently, rising insurance premiums (Defra 2013).
The insurance scheme indirectly provides some discouragement from building in high-risk areas because flood insurance is one of the determining factors for assessing the mortgagability of a property, and therefore ultimately the ability to sell it (Surminski et al. 2015). Additionally, the ties to prevention are strengthened through the exclusion of new properties, i.e., those built after January 2009, from the premium capping and cross-subsidization that Flood Re affords high-risk properties. Solicitors' best practice guidelines indicate that flood risk should be considered in conveyancing transactions (The Law Society 2016), and sellers are required to declare known flood risk and occurrences. However, this is an area that requires strengthening because other considerations often outweigh flood risk. Pryce et al. (2011) argue that house prices do not sufficiently reflect levels of flood risk and that the continued availability and subsidizing of insurance have made the housing market somewhat insensitive to flood risks (Ball et al. 2013), thereby undermining efforts to prevent increasing flood risks.

In the Netherlands, compensation is paid from general government funds, so no differentiation is made between where people live. The default situation is that areas are protected by dikes. Within these areas, a duty of care of the government to provide legally binding flood safety standards exists. Damages occurring in areas outside the protection of the flood defense structures are not entitled to compensation based on the CCA. The pilot insurance scheme, the Neerlandse, adopts risk differentiation because it determines the costs of the premiums based on, among other things, the available flood risk maps. The added value of an insurance scheme in the Netherlands has been subject to debate for years. Aerts (2009) stated that the surplus value of such an insurance regime would be that people who are living outside a dike-protected area would be compensated. However, if this insurance coverage were not mandatory, the premiums might become too high for those people to bear. Only mandatory insurance whereby inhabitants of the "safe" areas contribute to insurance costs would alleviate this affordability barrier. However, from a national perspective, the value of introducing a mandatory insurance regime for all Dutch citizens in addition to the existing CCA is questionable considering the small percentage of people living outside the dike areas.

\section{Recovery and flood mitigation}

Whereas the prevention strategy is, albeit not always explicitly, a factor in all four of the ex post compensation mechanisms, the link between flood recovery and flood mitigation is weaker. For instance, the Belgian ex post mechanism establishes a clear link with preventing flood risks by discouraging people from building in high-risk areas; however, it is deficient in promoting mitigation measures. The Insurance Act makes no reference to incentives for policyholders to adopt adaptive building measures. Whether these types of measures are taken into account, e.g., in terms of premium benefits, is at the discretion of individual insurers (Bruggeman 2011). In general, premium differentiation is inherent to the functioning of insurance schemes; however, this does not correspond to a systematic consideration of mitigation measures in the ex post compensation schemes analyzed. Moreover, there are no provisions for dealing with buildings in designated high-risk areas that may be excluded from coverage or premium capping but that have been built adaptively or have been flood proofed. Insurers are hesitant to take into account measures requiring human interaction, especially with regard to already 
existing buildings, whereas structural measures carried out at the time of construction are more commonly included in an insurer's risk assessment (telephone interview, insurance professional from the umbrella organization for insurers, 2015). This is one of the factors of uncertainty because it is often not clear how specific flood-proofing measures decrease the flood risks (Keskitalo et al. 2014). Empirical evidence, not only in Belgium but also at a broader geographic scale, on if and how risk reduction measures are being taken and their level of effectiveness is lacking (Hudson et al. 2016). Initiatives have been taken by the Flemish authorities to develop a scoring system for preventive measures taken for individual properties (interview, civil servants from the Flemish Environment Agency [Vlaamse Milieumaatschappij, or VMM], 2014), but these have not yet been realized or translated into practice.

In France, adaptive building is not a factor that is taken into account in a structural and transparent manner in the CAT-NAT regime. However, the risk reduction plans are supposed to, in theory, promote mitigation measures. One possibility to strengthen the link between compensation and mitigation is to condition the compensation of damages to the effectiveness and efficacy of the mitigation measures adopted prior to the occurrence of the natural disaster to incentivize public and private actors. Attempts have been made to link compensation to the adoption of specific measures. Article L.125-1 of the Insurance Code states that compensation is possible only if traditional mitigation measures were not sufficient to prevent the risk, a condition that is strictly interpreted by the courts. The fault of the insured must be sought to deprive them from the CAT-NAT guarantee (Cass. 2e civ., 13 January 2012, Mr. and Mrs. X., req. no. 10-28.003). For instance, this fault exists when damages could have been avoided if facilities had been built correctly (Cass. 1re civ., 7 February 1995, Cie La Bâloise, req. no. 91-16.706). For buildings located in an area that is not covered by a PPRI, the Insurance Code stipulates that compensation received following floods can only be used to retrofit buildings (article L.121-17). These restoration measures are prescribed by the mayor of the area in question. This restrictive interpretation does not encourage households to act in a proactive way to protect themselves against floods (Hourdeau-Bodin 2015). Hudson et al. (2016) argue that incentivizing mitigation in France is weakened by the lack of risk-reflective pricing, and until greater premium differentiation is implemented, there is unlikely to be much positive progress in this regard (Poussin et al. 2013).

Currently, in England, Flood Re does not explicitly provide for mitigation measures as part of the insurance policy (Surminski and Eldridge 2014). Under both the pre-Flood Re approach and the new system, properties are, in theory, able to benefit via a premium reduction from flood proofing or other risk reduction measures. Whether a premium reduction is available, as well as what is included or excluded and the amount of any deductible, is at the discretion of the individual insurer. Evidence suggests, however, that the numbers of properties that have actually benefited in such a way is limited (Bell 2011, Cobbing and Miller 2012). To date, it has been quite difficult for households to achieve a premium reduction, in part, because premiums for many have been disproportionately low (ABI 2010); therefore, it is only where premiums have been very large or properties excluded from coverage because of repeated flooding that there is the scope for reductions. Under Flood $\mathrm{Re}$, the aim is to transition to a situation whereby premiums reflect flood risk; hence, with higher risks there should be more possibility for incentivizing risk reduction at the household scale. Despite this, there are still significant barriers to be overcome. To benefit, households often will have to submit evidence, generally via a privately commissioned survey, to demonstrate the reduction of the risk presented by any household measure (Cobbing and Miller 2012). Similar to the insurers in Belgium, both insurance professional interviewees and other studies (e.g., Ball et al. 2013, Flood Re 2016) suggest that despite the growing evidence base (JBA Consulting 2012, Defra 2014, Environment Agency 2015), concern remains within the insurance industry about the effectiveness of such property-scale risk reduction and that some measures are contingent on action to reduce damages, e.g., shutting of gates or installation of flood doors. As such, there is no guarantee that these measures will be implemented in time and result in damage reduction. Monitoring and enforcing these actions will be difficult for insurers and introduce increased administrative costs, which would make any reduction in premiums less attractive. Furthermore, Ball et al. (2013) indicate that insurers find it difficult to account for the effects of some of these measures in terms of pricing and that the competitiveness of the market means that profits are low and there is little space to offer reductions (Thieken et al. 2006). Although incentivizing risk reduction is considered as one of the key benefits of Flood Re, the first transition plan (Flood Re 2016) provides little detail about how some of the aforementioned barriers will be overcome.

Similar to the other countries studied, in the Netherlands, mitigation measures are not structurally anchored in the ex post compensation mechanisms. First, according to the terms of the insurance policy, the value of the insured property is determined by the "home contents and rebuilding value indicator" of the Neerlandse or a taxation report of a sworn broker or assessor. The premium cost is also determined by the location of the property and its flood risk profile. According to the publicly available information, the presence of adaptive measures does not systematically form part of the determination of premium cost. There have been suggestions to lower taxes raised by water authorities to fund flood defense work for those who have reduced their own risk. However, this of course relates to prevention or defense, rather than being explicitly linked to recovery. Second, the CCA does not promote mitigation at the individual scale. This introduces the notion of "charity hazard" (Raschky and WeckHannemann 2007), which suggests that if citizens can rely on compensation for damages, there will be less incentive to try to either purchase insurance or reduce their risk. However, the CCA is viewed as a last resort because of the extensive focus on prevention and defense. Furthermore, the CCA does not compensate for all losses and is enacted infrequently, so the degree to which households are discouraged from risk reduction by the presence of this mechanism is limited. Because the government is not willing to make radical changes to this system, in the near future the recovery strategy will not by itself stimulate adaptive building. However, the notion of individual adaptation is complicated by the Dutch geographic situation. Some areas are at risk from such deep flooding, e.g., more than $3 \mathrm{~m}$, that it would be infeasible to reduce flood risks through individual property mitigation measures; therefore, for some households, self- 
mitigation options are limited. For those who own property outside the dike rings, there might be an incentive to take mitigation measures because in these areas the water authorities have no duty of care to protect against floods. Because not every flood will be designated as a "disaster" under the CCA, residents of these unprotected areas, mostly farmers, have already been adopting mitigation measures and are familiar with the risks of flooding. More problematic are new residents in unprotected areas who are less aware of flood risks. A possible way of creating more adaptive building would be by virtue of awareness campaigns, the use of subsidies, or building requirements.

Finally, public-private synergies, i.e., the manner in which the legislative and policy frameworks interact with market-based flood insurance, are important aspects of the linkages we analyzed. In Belgium, one of the recommendations identified by the evaluation of the 2010 floods for the Flemish region was that the VMM, which manages the first-category nonnavigable watercourses, and the major actors in the insurance market should cooperate more firmly (VMM 2011). More specifically, it was suggested that an agreement should be made between water managers and Assuralia, the Belgian professional association of insurance companies, with the goal of mutually sharing data on natural disasters. However, this agreement has not been finalized hitherto. Concerns have been raised by certain water managers, e.g., civil servants from the VMM, involved in the development of the preventive instruments that they do not have a clear view on how the insurance sector calculates the relevant fees applicable in risk prone areas (interview, civil servants from the VMM, 2014). There also seems to be a discrepancy in how building in flood prone areas is perceived by the stakeholders' active in the context of the prevention or mitigation strategy and the insurance industry. In the insurance realm, it would be difficult to introduce a mechanism whereby premiums would be lowered for buildings that are in flood prone areas but are built adaptively because, as previously mentioned, the effectiveness of the measures is still uncertain. However, the stakeholders active in the water management sector argue that certain measures are robust enough to justify a decrease in premiums, for example, building techniques to raise the threshold of properties (interview, insurance professional responsible for product management in Belgian bank, 2014). Indeed, there is empirical evidence to suggest that the effectiveness of some individual-scale mitigation measures is greater than initially evaluated and that they can lead to substantial reductions in flood damages (Poussin et al. 2015), although the effectiveness varies between different flood characteristics. In any case, water management stakeholders acknowledge that there is a need for better cooperation with the insurance sector (interview, civil servants from the VMM, 2014).

Table 3 provides a summary of the analysis of existing instruments linking flood risk prevention and recovery and flood mitigation and recovery. Furthermore, this table contains references to measures that, to date, are not being used by the four countries that we have discussed but that, if implemented, might better operationalize recovery-prevention-mitigation synergies (see, e.g., Priest 2014, Surminski and Eldridge 2014, Hochrainer-Stigler et al. 2015, Linnerooth-Bayer and Hochrainer-Stigler 2015, Surminski et al. 2015, Hudson et al. 2016). The analysis previously mentioned and presented in Table
3 forms the basis for recommendations for strengthening the links between strategies and creating a more resilient triangle.

\section{LESSONS LEARNED FOR A RESILIENT TRIANGLE}

Evaluative criteria have been used to highlight the extent to which other individual-level FRM strategies are linked to flood recovery mechanisms. Resilience against flooding can be maximized where the varying strategies used to manage flood risk are coordinated and provide reinforcing actions. Ensuring that one strategy does not undermine the effectiveness of another will provide the most effective and efficient outcomes from FRM. Analysis has shown that despite the great potential for linking and aligning flood risk strategies, the four countries analyzed are not maximizing this potential fully (see Table 3 ). All countries do, however, have some linkages between recovery and other FRM strategies, and there are examples of good practices, which might be transferred between countries and are applicable more widely. Additionally, these examples provide insights into the obstacles to linkage, which can be used to highlight opportunities for strengthening existing links or creating new ties.

Figure 2 summarizes the types of measures that are possible for linking recovery strategies with risk prevention, i.e., through keeping people and property out of the flood risk zone, and recovery with individual-level mitigation, i.e., through incentivizing individuals to reduce the risk to their properties. The numbered list in Figure 2 provides examples of the structural legal and/or policy mechanisms that in some cases are being used or could be adopted elsewhere to better improve these linkages and more effectively integrate and align FRM strategies.

Prevention and recovery: discouraging building in high-risk areas Preventing the exposure of people and property is a critical component of any comprehensive FRM approach. Recovery mechanisms offer a large potential for disincentivizing new development away from flood risk areas, particularly high flood risk areas. It should also be ensured that recovery mechanisms do not undermine development control strategies that aim to prevent increasing flood risk exposure. A good practice in this area is the Belgian system, whereby, on the basis of the Insurance Act, (1) insurers can refuse coverage for those buildings constructed in high-risk areas after 23 September 2008, or if they do cover, (2) the governmentally set cap on the insurance fee does not apply. These actions are effective because, among others, the measures are legally enshrined within the recovery mechanism (Figure 2, point 1). A similar example of this nature comes from the Flood Re scheme, whereby properties built after 1 January 2009 are excluded from the premium capping and the cross-subsidization offered. It is good practice to try to prevent increasing the problem in high-risk areas, but, particularly in the United Kingdom, until house prices become more sensitive to flood risk, significant disincentives to (re)develop or reside in flood risk areas are unlikely (Pryce et al. 2011, Ball et al. 2013). Without stronger links to house value, recovery mechanisms may continue to fail to discourage increasing development in flood risk areas.

\section{Mitigation and recovery: general}

In terms of the link between individual-scale mitigation and recovery measures, there is still potential to strengthen links because none of the four analyzed schemes have been successful in establishing strong and systematic requirements (Figure 2, 
Table 3. Evaluation of linkages in the selected countries.

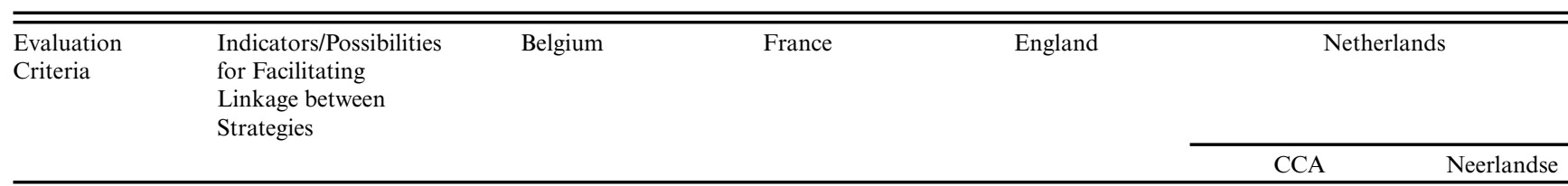

Strategy of prevention:

The ex post compensation mechanism facilitates "keeping people away from the water" in a structural manner.

\begin{tabular}{|c|c|c|c|c|c|}
\hline $\begin{array}{l}\text { Possibility for insurers/ } \\
\text { compensation } \\
\text { mechanism to exclude } \\
\text { property in high-risk } \\
\text { areas }\end{array}$ & $\begin{array}{l}\text { Yes, for buildings } \\
\text { built after } 23 \\
\text { September } 2008\end{array}$ & $\begin{array}{l}\text { No, all citizens } \\
\text { contribute }\end{array}$ & $\begin{array}{l}\text { Yes, but little evidence } \\
\text { of occurrence }\end{array}$ & $\begin{array}{c}\text { Yes, only outside the } \\
\text { dike area }\end{array}$ & $\begin{array}{l}\text { N/A (not } \\
\text { regulated) }\end{array}$ \\
\hline $\begin{array}{l}\text { Exclusion of new } \\
\text { properties from } \\
\text { insurance }\end{array}$ & No & No & $\begin{array}{l}\text { Partly; new properties } \\
\text { after January } 2009 \text { are } \\
\text { excluded from } \\
\text { premium capping. }\end{array}$ & No & No \\
\hline $\begin{array}{l}\text { Mechanism of } \\
\text { excluding content from } \\
\text { coverage based on risk }\end{array}$ & Is possible & Is possible & $\begin{array}{l}\text { Is possible, but little } \\
\text { evidence of } \\
\text { implementation }\end{array}$ & N/A & Is possible \\
\hline $\begin{array}{l}\text { Deductibles can be } \\
\text { modulated based on } \\
\text { risk }\end{array}$ & $\begin{array}{l}\text { Yes, but cap } \\
\text { pursuant to } \\
\text { Insurance Act }\end{array}$ & $\begin{array}{l}\text { Yes, but only if there is } \\
\text { no PPRI covering the } \\
\text { risk area }\end{array}$ & $\begin{array}{l}\text { Is possible, but little } \\
\text { evidence of occurrence }\end{array}$ & N/A & Is possible \\
\hline
\end{tabular}

Strategy of mitigation:

The mechanism incentivizes individuals to take adaptive building measures and retrofitting in a structural manner.

mechanism is based on $\quad$ applied $\quad$ principle insurers could

prevention, defense, or require measures for

mitigation measures. insurability

Premiums take in

Discretion of Discretion of insurer Discretion of insurer

account adaptive insurer

building measures.

Mechanism to ensure

No Possibly, for areas not

Not present in the

policy and currently

received following

covered by PPRI

not part of Flood Re,

but repair and renew

grants aimed to do this.

Systematic cooperation and coordination between public and private actors

Sharing of data, Data are Yes

alignment of

considered

Data are considered commercially sensitive, cartography

commercially

sensitive, so little

so little data sharing.

Yes, but only in the

way that all data are

data sharing.

freely accessible

Yes; they use publicly provided data and flood

maps.

Link between water management and ex post compensation scheme

$\begin{array}{lll}\text { Bridging mechanisms } & \begin{array}{l}\text { Link as a result of } \\ \text { to establish the link }\end{array} & \begin{array}{l}\text { insurance } \\ \text { restrictions for }\end{array} \\ \text { between the two } & \text { and PPRI } \\ \text { sectors, e.g., tools for } & \text { buildings built } \\ \text { identifying high-risk } & \text { after 23 September } \\ \text { zones, implications for } & 2008, \text { no } \\ \text { both ex post } & \text { structural bridging } \\ \text { compensation and } & \text { mechanisms } \\ \text { spatial planning } & \end{array}$

Much engagement between the insurers' representatives and authorities
No direct link

because of the formal responsibility of water managers to ensure protection against floods; no direct link between ex post compensation and spatial planning
Yes; they use publicly provided data and flood maps.

N/A
No
Compulsion of insurance uptake
In theory, no; in practice, yes
Partly yes; landlords do not have to insure themselves, except for coownership spaces, but tenants have to insure themselves. required for a mortgage; otherwise, no. However, generally high penetration. 


\begin{tabular}{|c|c|c|c|c|c|c|}
\hline & $\begin{array}{l}\text { Instruments raising } \\
\text { awareness for flood } \\
\text { risks, e.g., as an } \\
\text { obligatory element of a } \\
\text { real estate } \\
\text { advertisement/ } \\
\text { transaction }\end{array}$ & $\begin{array}{l}\text { Yes, in the water } \\
\text { management } \\
\text { sphere in } \\
\text { Flanders; the duty } \\
\text { to inform }\end{array}$ & $\begin{array}{l}\text { Yes, through the state of } \\
\text { natural and } \\
\text { technological hazards } \\
\text { (duty to inform). The } \\
\text { state of natural and } \\
\text { technological hazards } \\
\text { must be given by } \\
\text { landlords to tenants } \\
\text { before the signature of } \\
\text { the leasing agreement } \\
\text { and to buyers before the } \\
\text { signature of the deal of } \\
\text { sale. }\end{array}$ & $\begin{array}{l}\text { Yes; sellers are required } \\
\text { to declare known flood } \\
\text { risk and occurrences. } \\
\text { Solicitors' best practice } \\
\text { guidance suggests it } \\
\text { should be considered, } \\
\text { but there is scope to } \\
\text { strengthen this process. }\end{array}$ & $\begin{array}{c}\text { No, only general } \\
\text { awareness-raising } \\
\text { campaigns }\end{array}$ & No \\
\hline \multicolumn{7}{|l|}{ Legal effectiveness } \\
\hline & $\begin{array}{l}\text { Legal provisions are } \\
\text { adequately followed up } \\
\text { and enforced. }\end{array}$ & $\begin{array}{l}\text { General issue of } \\
\text { enforcement } \\
\text { bottleneck in the } \\
\text { water } \\
\text { management } \\
\text { sphere }\end{array}$ & Insufficient & $\begin{array}{l}\text { Flood Re: Legal } \\
\text { requirements exist, e.g., } \\
\text { to implement } \\
\text { transition plan, but it is } \\
\text { unclear how effective } \\
\text { these will be at } \\
\text { achieving goals. }\end{array}$ & $\begin{array}{l}\text { Yes, but the CCA is } \\
\text { effective only in those } \\
\text { cases in which a flood } \\
\text { has been designated } \\
\text { as a disaster, and it } \\
\text { will not compensate } \\
\text { all damage to } \\
\text { everyone. }\end{array}$ & N/A \\
\hline
\end{tabular}

CCA, Calamities Compensation Act; N/A, not available; PPRI, community-based plans for the prevention of natural risks.

point 2). In England, one of goals of Flood Re is to increase household ownership of flood risk and encourage individual risk reduction action (Defra 2013). The current Flood Re implementation plan (Flood Re 2016) insufficiently describes how to overcome some of the recognized barriers to implementation of risk reduction, including awareness of suitable measures to reduce risk (Kunreuther et al. 2013); the benefits of doing so and the cost-effectiveness of measures in reducing damages (Kunreuther 1996, Kunreuther et al. 2013, Poussin et al. 2015); and whether any incentives offered, such as premium reductions, are sufficient to promote action (Thieken et al. 2006, Ball et al. 2013). A best practice from the French insurance system is the link between CAT-NAT and the funding of large-scale defense and mitigation, through the financing of the Barnier Fund (Cans 2014). However, a criticism of the approach is that it does not do enough at the individual level to promote and incentivize mitigation (Michel-Kerjan 2001, Poussin et al. 2013, Hudson et al. 2016). In a fully public compensation scheme, as in the Netherlands, significant incentives for reducing flood risks are likely situated outside the scope of the recovery strategy and are addressed more traditionally by flood defense and risk management. Indeed, because of the low penetration of flood insurance in the Netherlands, if a financial incentive were to be granted, the direct provision of household subsidies for mitigation would likely be more successful than any modification of premiums (interview, Association of Dutch Insurers, 19 November 2014).

\section{Legislative reforms to improve linkages}

Those schemes analyzed have highlighted that there are existing legal barriers (see Figure 2, point 5) impeding the effectiveness of linkages between ex post compensation mechanisms and prevention and mitigation. As described previously, in England, the presence of financial rules and the Competition Act of 1998 has been a barrier for insurers from working together to mandate mitigation (Priest et al. 2005). However, there is more scope in the new Flood Re approach to make improvements in this area because it brings insurers together through the pooling of risks.
The lack of transparency in the declaration procedure acknowledging a flood event as a natural disaster currently hampers legitimacy within the French CAT-NAT regime. The criteria for such an acknowledgment have not been set out through legislative instruments and are often considered as biased and partisan. The elaboration of clear, strict, and exhaustive criteria would overcome this bottleneck. Moreover, in France, the promotion of mitigation measures could be improved through legislative reform of the Insurance Act. Penalizing violations of prevention and mitigation measures set forth by the relevant PPRI could be made mandatory instead of optional. Furthermore, CAT-NAT premium rates could be differentiated based on the consideration of whether prevention and mitigation measures have been adopted. Suggestions have been made to differentiate the set premium rates according to the situation of households (Dumas et al. 2005, Cour des Comptes 2009, Poussin et al. 2013, Hourdeau-Bodin 2015, Hudson et al. 2016). To maintain the constitutional solidarity principle, a reduced rate of $9 \%$ could be proposed for households situated in no-risk territories. For those insured households located in a flood zone, an intermediate rate of $12 \%$ could be applied if they declare themselves in compliance with regulatory requirements contained in the PPRI. For those who do not respect the aforementioned requirements, a higher rate of $30 \%$ could be applied. This scheme would allow a shift from the égalité principle toward an "equity principle." To this end, a bill has been introduced to the senate in April 2012 to amend the 1982 Insurance Act. This bill defined three main goals: (1) objectify the recognition process of natural disasters to enhance transparency and equity, (2) encourage prevention efforts, and (3) treat in an appropriate way the risk of subsidence. Despite some positive signs, there have been few resulting actions. First, the proposed act only addressed local authorities and businesses (Impact Study Reform Insurance Act of 2012), and it was introduced in the context of the 2012 presidential and legislative elections, meaning that the proposed reforms were not discussed by Parliament. Although no action has resulted, the issues remain on the political agenda, and despite a change in political majority, the current French government has expressed 
Fig. 2. Measures and instruments to strengthen the links between strategies.

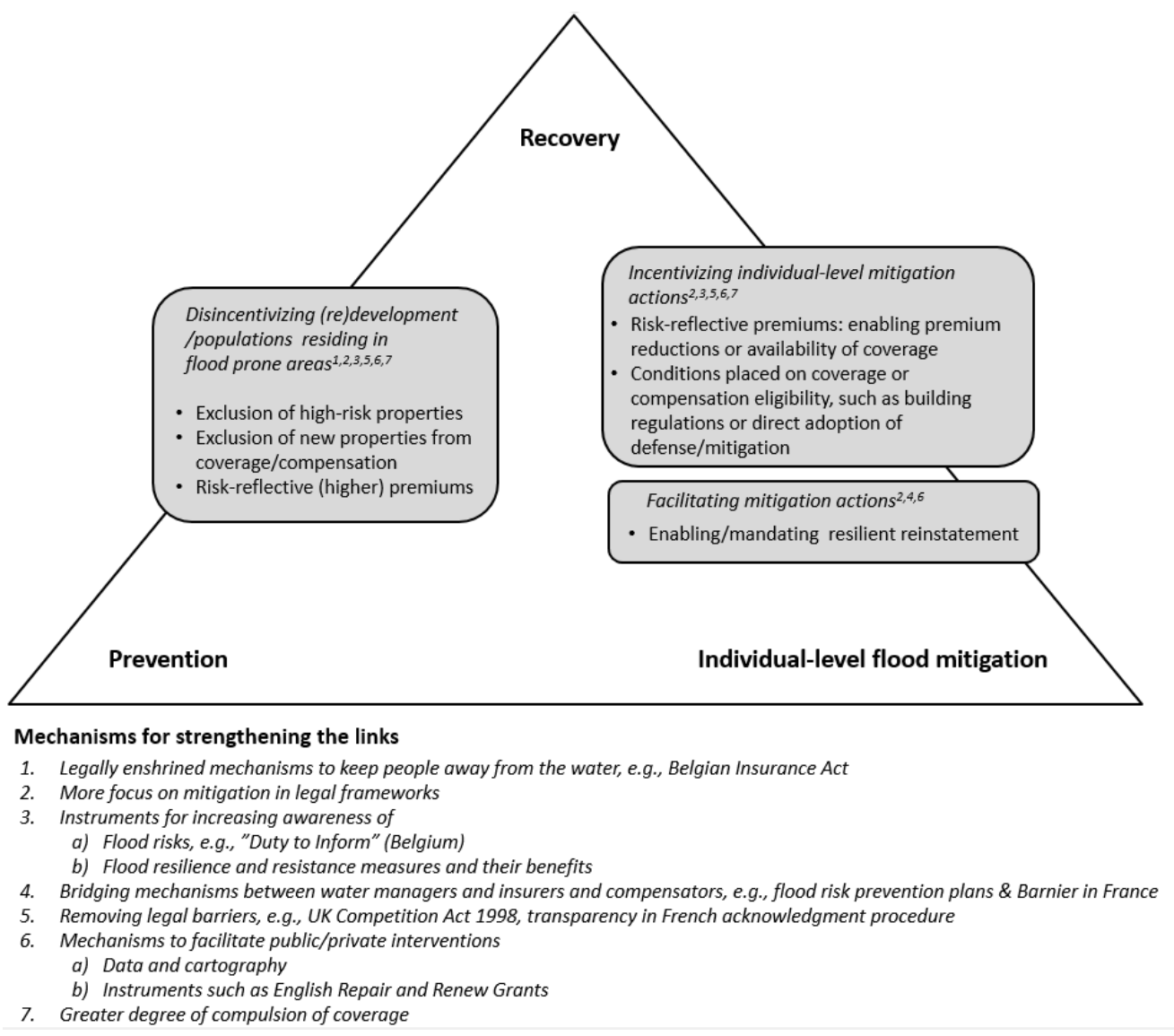

its desire for change and in 2014 presented different reforms. These reforms would prevent payout delays and encourage better coordination of the actors involved in the CAT-NAT process.

\section{Instruments to promote linkage with the mitigation strategy}

In England, certain ad hoc mechanisms have been applied in recent years to promote individual-scale mitigation strategies following flooding. The governmental Repair and Renew Grant is an example of an instrument that could, provided its implementation be more adequately framed and guided, hold promise and emerge as a good practice. Promoted following the 2013-2014 floods, a grant was introduced that offered up to $£ 5000$ specifically targeted toward resilient reinstatement. Its original success was limited, and uptake was low caused mainly by little awareness of potential measures, a lack of promotion of the scheme and other organizational issues related to how to claim, and the lack of accreditation of measures (interview with AXA underwriting professional, United Kingdom, 2014). Despite its limited uptake, the idea behind the grant, i.e., providing specific funding for resilient reinstatement in the aftermath of a flood, is conducive to a resilient recovery strategy. An approach such as this avoids two existing barriers to the linking of FRM strategies. First, it overcomes insurers' concerns about increased claim costs; that is, when interviewed, underwriters from three leading UK insurers suggested that a current barrier was the unwillingness of companies to pay the higher costs necessary to make a property more resilient or resistant. Second, it circumvents the legal barriers (see Figure 2, point 5) preventing private market insurers working together to mandate mitigation and defense, i.e., the UK Competition Act of 1998. The grant could, for example, also be relevant for countries with an exclusively public ex post compensation mechanism and assist individuals to afford measures, either through grants or loans, to reduce their risk to future events.

\section{Instruments to promote public awareness}

As recognized as a contributing factor to the low uptake of the Repair and Renew Grant, public awareness is an important aspect for FRM in general and, more specifically, with respect to the linkages discussed. This relates to raising awareness of the population in terms of (1) flood risks and their implications, (2) the importance of adaptive building and resilient reinstatement, and (3) the actions that can be taken during a flood event. Clearly, if a population is unaware of its flood risk and possible actions to reduce risk, it will be difficult for individuals to act positively and responsibly. The nature of private market insurance mechanisms provides an annual opportunity at policy renewal to inform policyholders of their flood risk. Attempts have been made to raise the awareness of citizens in terms of adaptive-building possibilities, e.g., the document on flood resilient construction for new building works in England (ABI 2009) and in Belgium (CIW 2011). Despite the usefulness of such information dissemination 
activities, these are generally voluntary. Informing roles and the strongest links occur where specific instruments have been developed to tackle this. In the Flemish region, the "duty to inform" is a legal instrument in the nexus between spatial planning and water management that requires sellers and long-term landlords, i.e., with rental contracts exceeding a period of 9 years, to disclose information on the flood prone character of the building (Decree Integrated Water Policy [Decree of 18 July 2003 on Integrated Water Policy, Belgian Official Journal, 14 November 2003], article 17bis). This instrument can be considered as a good practice in the FRM realm (Mees et al. 2016). The creation of this instrument was induced by the concern that citizens are often unaware of the flood prone character of the building they are occupying or the parcel they are aiming to develop. Flood riskrelated information is required to be widely disseminated by the property owner, the real estate broker, and the notary, e.g., as part of every online advertisement and brochure (Decree Integrated Water Policy, article 17bis). Once the transaction is completed, the information should be included as a water paragraph in the agreement in question. This instrument could be a useful addition to legal and policy frameworks in other EU member states. In the Flemish region, the scope of the duty to inform should be sufficiently linked to the high-risk areas within the insurance context specifically.

Another example of an awareness-raising instrument is the legal obligation in France for tenants to have coverage for natural disasters through the household insurance policy (Law No. 89-462 [Act No. 89-462 of 6 July 1989 Aimed at Rental Relationships Improvement], article 7). Tenants must demonstrate to the owner that the contents are covered at the beginning of their rental contract and, if requested by the owner, on a yearly basis. Pursuant to the ALUR (Accès au logement et un urbanisme rénové) Act (Act No. 2014-366 of 24 March 2014 Related to the Access to Housing and Urban Planning Renovated), the landlord may replace the tenant as the policyholder if the tenant has not done so within a month of being notified. One of the key features of the English Flood Re scheme should be to inform policyholders that they have been entered into the "at risk" pool and provide information about their level of risk and actions that could be taken to reduce it. However, there are currently no rules within the legislation or policy governing the scheme to ensure that this is undertaken. Importantly, raising awareness will not resolve all issues. As Bubeck et al. (2013) highlight, it is not only awareness deficiencies that need to be addressed in relation to the encouragement of the uptake of risk reduction. In their study of households along the Rhine, inactivity and delaying action until the future were reducing the resilience of some households. This reinforces the need to also effectively incentivize the uptake of these measures.

\section{The use of bridging mechanisms}

As mentioned previously, public-private stakeholder dynamics are particularly important for linking strategies and ensuring that approaches reinforce, rather than undermine, each other. Ex post compensation for natural disasters, in casu floods, is different from other insurance products. Although the degree varies, flood risk insurance is in some way or another impacted by governmental action, be it through flood risk cartography, spatial planning measures, flood defense actions, or direct intervention in the ex post compensation. If appropriate in the country-specific settings, existing bridging mechanisms (see Van Rijswick 2014; Gilissen et al. 2016) between the spatial planning sector and water managers, such as the VMM, could be reevaluated and strengthened to take into consideration recovery. The water test, applicable in Belgium (the Flemish region) and the Netherlands, requires that the impact on the water system of any plan, program, or, in the Flemish region, permit is scrutinized, and subsequent measures to mitigate this impact are adopted. In this regard, improved information exchange between the representative organization(s) for the insurance industry and water managers on the one hand and the land use and building permit-issuing authorities on the other hand would be particularly useful.

Besides the above-mentioned country-specific vulnerabilities and recommendations, several, more broadly applicable, recommendations ensue from the analysis we have presented:

- The importance of legally enshrined mechanisms within an ex post compensation scheme pursuant to the prevention strategy, i.e., to prevent (re)development in high flood risk areas. An example of this is the Belgian risk differentiation approach (Bruggeman 2011).

- Measures to reduce risk at an individual level through mitigation should be more strongly and systematically incentivized by recovery mechanisms. This might be through structured premium increases, such as are planned as part of Flood Re, or through requirements for obtaining coverage (Surminski et al. 2015, Hudson et al. 2016). This recommendation implies that more research needs to be done to scrutinize and raise awareness of possible risk reduction measures and their (cost)effectiveness, and that greater clarity about possible premium reductions is needed (Ball et al. 2013).

- Specific legal or policy instruments to enhance the awareness of flood risks on the nexus between spatial planning, adaptive building management, and water management should be developed, establishing better links with the ex post compensation mechanisms. For example, the abovementioned duty to inform that exists in the Flemish region, as illustrated previously, is a versatile instrument that could be interesting for other countries to scrutinize (Mees et al. 2016).

\section{CONCLUDING REMARKS}

We have engaged with the existing literature on recovery mechanisms and their use for enhancing resilience from flood risks (among others: Kunreuther 1996, Michel-Kerjan 2001, Faure 2007a, Botzen and Van Den Bergh 2008, Crichton 2008, Faure and Bruggeman 2008, Mehlhorn and Hausmann 2012, Poussin et al. 2013, Surminski et al. 2015). The research has specifically tackled the manner in which these mechanisms promote the adoption of preventative and mitigation measures at the individual level. Flood recovery is generally accessed at the individual level either through purchasing a policy or reclaiming damages and, as such, offers a clear link to inducing or informing other flood management decisions and responsibility taking at the household level, a move that is advocated by many European countries (Alexander et al. 2016, Ek et al. 2016, Kaufmann et al. 2016, Larrue et al. 2016, Matczak et al. 2016, Mees et al. 2016). However, analysis has highlighted that although there is great 
potential to better link flood risk prevention and individual-scale mitigation, in the four examples presented, these links are often lacking or are ineffective. This is particularly the case for the recovery-mitigation nexus. Currently, many of the approaches to encourage the uptake of defense and mitigation or discourage development are implicit and indirectly provided and, as such, are not being maximized. The most effective links have been created by specific instruments or requirements in legislation and policy, and therefore, our recommendations suggest the adoption of more targeted and mandatory linking mechanisms. Despite not resolving all of the issues and barriers, clearer linkages between FRM strategies provide the best chance that they will be effectively implemented and that strategies contradicting or undermining each other will be avoided.

Although we have analyzed only four European recovery approaches, these include a range of different types of insurance, with varying degrees of public-private involvement, as well as a compensation approach. Therefore, the analysis covers many of the possible types of existing flood recovery mechanisms. Consequently, many of the recommendations concerning the strengthening of legal or policy instruments are applicable in a wider international context. Future research could further test the mechanisms for strengthening each of the links and identify more specific recommendations within the national context. For example, would better national quality standards or accreditation for individual-scale products encourage insurers to offer premium reductions, provide incentives, and stimulate uptake? Further analysis of the future role of the EU in this matter should be conducted. We have focused principally on the national-level comparisons. An analysis of the legal feasibility of a comprehensive EU ex post compensation scheme is beyond the scope of this research. However, based on, for example, the reactions of the EU member states to the 2013 green paper on insurance for natural and anthropogenic disasters, there would not be broad support at this time for a top-down approach and a harmonization of insurance for natural disasters throughout the EU (Faure and Bruggeman 2013, European Commission 2014, Surminski et al. 2015). However, rules and guidelines issued at this level can have an important steering effect for member states to promote these linkages. For example, the Solidarity Fund could further enhance risk awareness and reduction at national levels through its allocation of funds or through the reporting obligations (Hochrainer-Stigler et al. 2015). Moreover, flood risk management plans issued in the context of the EU Floods Directive (European Parliament, Council of the European Union 2007) could include more references on how recovery schemes are promoting prevention and mitigation measures at individual levels.

In conclusion, increasing resilience to flooding on a broad scale in the face of worsening risks will ultimately require a greater alignment of strategies that reinforce, rather than undermine, each other. Despite many of the inherent problems identified, strengthening the flood risk prevention, flood recovery, and flood mitigation triangle offers great unexploited potential for strengthening resilience to flooding, in particular at the individual level.
${ }^{[1]}$ In the case of the Netherlands, we concentrate on recovery from coastal and fluvial flooding, rather than pluvial flooding. For the latter, insurance is provided as part of a standard household policy, with the potential for additional flood insurance that can be purchased as an add-on.

[2] Throughout the STAR-FLOOD project, 70 interviews have been conducted in Belgium, 61 in England, 64 in France, and 45 in the Netherlands. These have been paramount in providing context for the linking of the strategies we have presented.

Responses to this article can be read online at: http://www.ecologyandsociety.org/issues/responses. $\mathrm{php} / 8592$

\section{Acknowledgments:}

This paper has been written in the framework of the European Union's Seventh Programme for Research, Technological Development, and Demonstration within the STAR-FLOOD project (grant agreement no. 308364). The authors would like to thank all the flood management professionals who agreed to be interviewed as part of this research and the two anonymous reviewers for their valuable and insightful comments.

\section{LITERATURE CITED}

Aerts, J. C. J. H. 2009. Onzekerheid Verzekerd. Inaugural Lecture. Vrije Universiteit, Amsterdam, the Netherlands.

Alexander, M., S. Priest, and H. Mees. 2015. Practical guidelines for evaluating flood risk governance. In C. Larrue, D. L. T. Hegger, and J. B. Trémorin, editors. Researching flood risk policies in Europe: a framework and methodology for assessing flood risk governance. STAR-FLOOD Consortium, Utrecht, the Netherlands.

Alexander, M., S. Priest, A. P. Micou, S. Tapsell, C. Green, D. Parker, and S. Homewood. 2016. Analysing and evaluating flood risk governance in England: enhancing societal resilience through comprehensive and aligned flood risk governance arrangements. STAR-FLOOD Consortium, Utrecht, the Netherlands.

Association of British Insurers (ABI). 2008. Revised statement of principles on the provision of flood insurance. ABI, London, UK.

Association of British Insurers (ABI). 2009. Climate adaptation: guidance on insurance issues for new developments. ABI, London, UK.

Association of British Insurers (ABI). 2010. Under-pricing of the flood element of home insurance for domestic customers at significant risk. ABI Research Brief. ABI, London, UK.

Ball, T., A. Werritty, and A. Geddes. 2013. Insurance and sustainability in flood-risk management: the UK in a transitional state. Area 45(3):266-272. http://dx.doi.org/10.1111/area.12038

Bell, A. 2011. Morpeth Flood Action Group insurance survey: results and analysis. Morpeth Flood Action Group, Morpeth, United Kingdom. [online] URL: http://www.morpethfloodaction. org.uk/assets/applets/Morpeth_Flood_Action_Group_Insurance_Survey. pdf 
Blanchard-Boehm, R. D., K. A. Berry, and P. S. Showalter. 2001. Should flood insurance be mandatory? Insights in the wake of the 1997 New Year's Day flood in Reno-Sparks, Nevada. Applied Geography 21(3):199-221. http://dx.doi.org/10.1016/S0143-6228 (01)00009-1

Botzen, W. J. W., and J. C. J. M. Van Den Bergh. 2008. Insurance against climate change and flooding in the Netherlands: present, future, and comparison with other countries. Risk Analysis 28 (2):413-426. http://dx.doi.org/10.1111/j.1539-6924.2008.01035.x

British Insurance Association/Fire Offices Committee (BIA/ FOC). 1961. Memorandum on flood cover to be provided by the private insurance market. BIA/FOC, London, UK.

Bruggeman, V. 2010. Compensating catastrophe victims: a comparative law and economics approach. Kluwer Law International, Alphen aan den Rijn, the Netherlands.

Bruggeman, V. 2011. A critical comparison of the main compensation mechanism for victims of natural catastrophes in Belgium and the Netherlands. With a law and economics twist. Journal for European Environmental \& Planning Law 8(1):46-61. http://dx.doi.org/10.1163/187601011X559718

Bubeck, P., W. J. W. Botzen, H. Kreibich, and J. C. J. H. Aerts. 2013. Detailed insights into the influence of flood-coping appraisals on mitigation behaviour. Global Environmental Change 23(5):1327-1338. http://dx.doi.org/10.1016/j.gloenvcha.2013.05.009

Cans, C. 2014. Traité de droit des risques naturels. Le Moniteur, Paris, France.

Chaffin, B. C., H. Gosnell, and B. A. Cosens. 2014. A decade of adaptive governance scholarship: synthesis and future directions. Ecology and Society 19(3):56. http://dx.doi.org/10.5751/ es-06824-190356

Cobbing, P., and S. Miller. 2012. Property level protection and insurance: main report - 2012. National Flood Forum, Bewdley, Worcestershire, UK.

Colle, P. 2006. De Wet van 17 September 2005 betreffende de Verzekering van Natuurrampen. Rechtskundig Weekblad 69 (23):881-885.

Collombat, P.-Y. 2012. Rapport d'information fait au nom de la mission commune d'information sur les inondations qui se sont produites dans le Var, et plus largement, dans le sud-est de la France au mois de novembre 2011. Sénat, Paris, France.

Coördinatiecommissie Integraal Waterbeleid (CIW). 2011. Overstromingsveilig bouwen en wonen. CIW, Erembodegem, Belgium. [online] URL: http://www.integraalwaterbeleid.be/nl/ publicaties/afbeeldingen/Overstromingsveilig $\% 20$ bouwen $\% 20$ en $\%$ 20wonen $\% 20-\% 20$ CIW.pdf

Cosens, B. 2010. Transboundary river governance in the face of uncertainty: resilience theory and the Columbia River Treaty. Journal of Land, Resources, and Environmental Law 30 (2):229-265.

Cosens, B. A. 2013. Legitimacy, adaptation, and resilience in ecosystem management. Ecology and Society 18(1):3. http://dx. doi.org/10.5751/ES-05093-180103

Cour des Comptes. 2009. L'Etat face à la gestion des risques naturels: feux de forêt et inondations. Cour des Comptes, Paris, France.
Crichton, D. 2008. Role of insurance in reducing flood risk. Geneva Papers on Risk and Insurance Issues and Practice 33 (1):117-132. http://dx.doi.org/10.1057/palgrave.gpp.2510151

Department for Environment, Food and Rural Affairs (Defra). 2013. Securing the future availability and affordability of home insurance in areas of flood risk. Defra, London, UK.

Department for Environment, Food and Rural Affairs (Defra). 2014. Post-installation effectiveness of property level flood protection. Final Report FD2668. Defra, London, UK.

Dietz, T., E. Ostrom, and P. C. Stern. 2003. The struggle to govern the commons. Science 302(5652):1907-1912.

Dumas, P., A. Macaire, A. Chavarot, C. Dimitrov, C. Quefellec, H. Legrand, and X. Martin. 2005. Mission d'enquête sur le régime d'indemnisation des victimes de catastrophe naturelle. Ministère des transports, de l'équipement, du tourisme et de la mer, Paris, France.

Ek, K., S. Goytia, M. Pettersson, and E. Spegel. 2016. Analysing and evaluating flood risk governance in Sweden. Adaptation to climate change? STAR-FLOOD Consortium, Utrecht, the Netherlands.

Environment Agency. 2015. Cost estimation for household flood resistance and resilience measures - summary of evidence . Report SC080039/R11. Environment Agency, Bristol, UK.

European Commission. 2014. Summary: responses received to the European Commission's green paper on the insurance of natural and man-made disasters. European Commission, Brussels, Belgium. [online] URL: http://ec.europa.eu/finance/consultations/2013/ disasters-insurance/docs/summary-report en.pdf

European Parliament, Council of the European Union. 2007. Directive 2007/60/EC of the European Parliament and of the Council of 23 October 2007 on the assessment and management of flood risks. Official Journal of the European Union L 288:27-34.

Faure, M. 2007a. Financial compensation in case of catastrophes: a European law and economics perspective. Law and Policy 29 (3):2-27.

Faure, M. 2007b. Insurability of damage caused by climate change: a commentary. University of Pennsylvania Law Review 155:1875-1899.

Faure, M., and V. Bruggeman. 2008. Catastrophic risks and firstparty insurance. Connecticut Insurance Law Journal 15(1):1-51.

Faure, M., and V. Bruggeman. 2013. Green paper on the insurance of natural and man-made disasters (COM(2013) 213 final): reaction of the Malta Forum of Legal Experts on Climate Change Adaptation. University of Malta, Msida, Malta. [online] URL: https://www.um.edu.mt/ data/assets/pdf file/0003/190182/

Reaction_on behalf_of the malta_forum_of_legal_experts_forclimate change adaptation.pdf

Flood Re. 2016. The first Flood Re transition plan: transitioning to an affordable market for household flood insurance. Flood Re, London, UK. [online] URL: http://www.nationalfloodforum. org.uk/wp-content/uploads/Flood-Re-Transition-Plan-Feb-2016FINAL..pdf

Folke, C., T. Hahn, P. Olsson, and J. Norberg. 2005. Adaptive governance of social-ecological systems. Annual Review of 
Environment and Resources 30:441-473. http://dx.doi.org/10.1146/ annurev.energy.30.050504.144511

Garmestani, A. S., and M. H. Benson. 2013. A framework for resilience-based governance of social-ecological systems. Ecology and Society 18(1):9. http://dx.doi.org/10.5751/ES-05180-180109

Gilissen, H. K., M. Alexander, J. C. Beyers, P. Chmielewski, P. Matczak, T. Schellenberger, and C. Suykens. 2016. Bridges over troubled waters: an interdisciplinary framework for evaluating the interconnectedness within fragmented domestic flood risk management systems. Journal of Water Law 25(1):12-26.

Graziadei, M. 2003. The functionalist heritage. Pages 100-128 in P. Legrand and R. Munday, editors. Comparative legal studies: traditions and transitions. Cambridge University Press, Cambridge, UK. http://dx.doi.org/10.1017/cbo9780511522260.005

Green, C., C. Dieperink, K. Ek, D. Hegger, M. Pettersson, S. Priest, and S. Tapsell. 2013. Flood risk management in Europe: the flood problem and interventions. STAR-FLOOD Consortium, Utrecht, the Netherlands.

Hartlief, T. 2014. Privaatrecht in nood. Pages 65-194 in E. R. Muller, T. Hartlief, B. F. Keulen, and H. R. B. M. Kummeling, editors. Crises, rampen en recht. Kluwer, Deventer, the Netherlands.

Hegger, D. L. T., C. Green, P. Driessen, M. Bakker, C. Dieperink, A. Crabbé, K. Deketelaere, B. Delvaux, C. Suykens, J. C. Beyers, M. Fournier, C. Larrue, C. Manson, W. Van Doorn-Hoekveld, M. Van Rijswick, Z. W. Kundzewicz, and S. Goytia Casermeiro. 2013. Flood risk management in Europe: similarities and differences between the STAR-FLOOD consortium countries. STARFLOOD Consortium, Utrecht, the Netherlands.

Hochrainer-Stigler, S., J. Linnerooth-Bayer, and A. Lorant. 2015. The European Union Solidarity Fund: an assessment of its recent reforms. Mitigation and Adaptation Strategies for Global Change. http://dx.doi.org/10.1007/s11027-015-9687-3

Hourdeau-Bodin, S. 2015. Risques naturels en zones côtières et assurance. Pages 141-158 in Les risques naturels en zones côtières. Presses universitaires de Rennes, Rennes, France.

Huber, M. 2004. Reforming the UK flood insurance regime: the breakdown of a gentlemen's agreement. Centre for Analysis of Risk and Regulation (CARR) Discussion Papers, DP 18. CARR, London School of Economics and Political Science, London, UK.

Hudson, P., W. J. W. Botzen, L. Feyen, and J. C. J. H. Aerts. 2016. Incentivising flood risk adaptation through risk based insurance premiums: trade-offs between affordability and risk reduction. Ecological Economics 125:1-13. http://dx.doi.org/10.1016/j. ecolecon.2016.01.015

JBA Consulting. 2012. Establishing the cost effectiveness of property flood protection: FD2657. Final Report. Department for Environment, Food and Rural Affairs, London, UK.

Kaufmann, M., W. Van Doorn-Hoekveld, H. K. Gilissen, and M. Van Rijswick. 2016. Analysing and evaluating flood risk governance in the Netherlands. Drowning in safety? STARFLOOD Consortium, Utrecht, the Netherlands.
Keskitalo, E. C. H., G. Vulturius, and P. Scholten. 2014. Adaptation to climate change in the insurance sector: examples from the UK, Germany and the Netherlands. Natural Hazards 71 (1):315-334. http://dx.doi.org/10.1007/s11069-013-0912-7

Kunreuther, H. 1996. Mitigating disaster losses through insurance. Journal of Risk and Uncertainty 12(2):171-187. http:// dx.doi.org/10.1007/bf00055792

Kunreuther, H. 2008. Reducing losses from catastrophic risks through long-term insurance and mitigation. Social Research: An International Quarterly 75(3):905-931.

Kunreuther, H., E. Michel-Kerjan, and N. Ranger. 2013. Insuring future climate catastrophes. Climatic Change 118(2):339-354. http://dx.doi.org/10.1007/s10584-012-0625-Z

Lamond, J., and E. Penning-Rowsell. 2014. The robustness of flood insurance regimes given changing risk resulting from climate change. Climate Risk Management 2:1-10. http://dx.doi. org/10.1016/j.crm.2014.03.001

Lamond, J. E., D. G. Proverbs, and F. N. Hammond. 2009. Accessibility of flood risk insurance in the UK: confusion, competition and complacency. Journal of Risk Research 12 (6):825-841. http://dx.doi.org/10.1080/13669870902768614

Larrue, C., S. Bruzzone, L. Lévy, M. Gralepois, T. Schellenberger, J. B. Trémorin, M. Fournier, C. Manson, and T. Thuillier. 2016. Analysing and evaluating flood risk governance in France: from state policy to local strategies. STAR-FLOOD Consortium, Utrecht, the Netherlands.

The Law Society. 2016. Flood risk. Practice Note. The Law Society, London, UK. [online] URL: http://www.lawsociety.org.uk/ support-services/advice/practice-notes/flood-risk/

Linnerooth-Bayer, J., and S. Hochrainer-Stigler. 2015. Financial instruments for disaster risk management and climate change adaptation. Climatic Change 133(1):85-100. http://dx.doi. org/10.1007/s10584-013-1035-6

Matczak, P., J. Lewandowski, A. Choryński, M. Szwed, and Z. W. Kundzewicz. 2016. Analysing and evaluating flood risk governance in Poland: looking for strategic planning in a country in transition. STAR-FLOOD Consortium, Utrecht, the Netherlands.

Mees, H., C. Suykens, J. C. Beyers, A. Crabbé, B. Delvaux, and K. Deketelaere. 2016. Analysing and evaluating flood risk governance in Belgium: dealing with flood risks in an urbanised and institutionally complex country. STAR-FLOOD Consortium, Utrecht, the Netherlands.

Mehlhorn, J., and P. Hausmann. 2012. Flood-an underestimated risk: inspect, inform, insure. Swiss Reinsurance Company, Zurich, Switzerland.

Michel-Kerjan, E. 2001. Insurance against natural disasters: do the French have the answer? Strengths and limitations. Cahier du Laboratoire d'Econométrie no. 2001-007. Ecole Polytechnique, Paris, France.

Moréteau, O. 2007. Policing the compensation of victims of catastrophes: combining solidarity and self-responsibility. Pages 199-218 in W. H. van Boom and M. Faure, editors. Shifts in 
compensation between private and public systems. Springer, Vienna, Austria. http://dx.doi.org/10.1007/978-3-211-71554-3_8

Nelson, R., M. Howden, and M. Stafford Smith. 2008. Using adaptive governance to rethink the way science supports Australian drought policy. Environmental Science \& Policy 11 (7):588-601. http://dx.doi.org/10.1016/j.envsci.2008.06.005

O’Neill, J., and M. O'Neill. 2012. Social justice and the future of flood insurance. Joseph Rowntree Foundation, York, UK.

Parliament of the United Kingdom. 2015. The Flood Reinsurance (Scheme and Scheme Administrator Designation) Regulations 2015, Statutory Instrument No. 1875. The Stationery Office, London, UK. [online] URL: http://www.legislation.gov. uk/id/uksi/2015/1875

Penning-Rowsell, E. C., and S. J. Priest. 2015. Sharing the burden of increasing flood risk: who pays for flood insurance and flood risk management in the United Kingdom. Mitigation and Adaptation Strategies for Global Change 20(6):991-1009. http:// dx.doi.org/10.1007/s11027-014-9622-z

Porrini, D., and R. Schwarze. 2014. Insurance models and European climate change policies: an assessment. European Journal of Law and Economics 38(1):7-28. http://dx.doi. org/10.1007/s10657-012-9376-6

Poussin, J. K., W. J. W. Botzen, and J. C. J. H. Aerts. 2013. Stimulating flood damage mitigation through insurance: an assessment of the French CatNat system. Environmental Hazards 12(3-4):258-277. http://dx.doi.org/10.1080/17477891.2013.832650

Poussin, J. K., W. J. W. Botzen, and J. C. J. H. Aerts. 2015. Effectiveness of flood damage mitigation measures: empirical evidence from French flood disasters. Global Environmental Change 31:74-84. http://dx.doi.org/10.1016/j.gloenvcha.2014.12.007

Priest, S. J. 2014. Review of international flood insurance and recovery mechanisms: implications for New Zealand and the resilience of older people. Project Report. Centre for Research Evaluation and Social Assessment, Wellington, New Zealand.

Priest, S. J., M. J. Clark, and E. J. Treby. 2005. Flood insurance: the challenge of the uninsured. Area 37(3):295-302. http://dx.doi. org/10.1111/j.1475-4762.2005.00633.x

Pryce, G., Y. Chen, and G. Galster. 2011. The impact of floods on house prices: an imperfect information approach with myopia and amnesia. Housing Studies 26(2):259-279. http://dx.doi. org/10.1080/02673037.2011.542086

Raschky, P., and H. Weck-Hannemann. 2007. Charity hazarda real hazard to natural disaster insurance? Environmental Hazards 7(4):321-329.

Reed, M. S., A. C. Evely, G. Cundill, I. Fazey, J. Glass, A. Laing, J. Newig, B. Parrish, C. Prell, C. Raymond, and L. C. Stringer. 2010. What is social learning? Ecology and Society 15(4):r1. [online] URL: http://www.ecologyandsociety.org/vol15/iss4/ $\underline{\text { resp } 1 /}$

Siems, M. M. 2014. Comparative law. Cambridge University Press, Cambridge, UK.

Smits, J. M. 2012. Elgar encyclopedia of comparative law. Edward Elgar, Cheltenham, UK.
Surminski, S., J. C. J. H. Aerts, W. J. W. Botzen, P. Hudson, J. Mysiak, and C. D. Pérez-Blanco. 2015. Reflections on the current debate on how to link flood insurance and disaster risk reduction in the European Union. Natural Hazards 79(3):1451-1479.

Surminski, S., and J. Eldridge. 2014. Flood insurance in Englandan assessment of the current and newly proposed insurance scheme in the context of rising flood risk. Centre for Climate Change Economics and Policy (CCCEP) Working Paper No. 161. CCCEP, London, UK. [online] URL: http://www.lse.ac.uk/ GranthamInstitute/wp-content/uploads/2014/02/WP144-Flood-insurancein-England.pdf

Thieken, A. H., T. Petrow, H. Kreibich, and B. Merz. 2006. Insurability and mitigation of flood losses in private households in Germany. Risk Analysis 26(2):383-395. http://dx.doi. org/10.1111/j.1539-6924.2006.00741.x

Van den Bergh, R., and M. G. Faure. 2006. Compulsory insurance of loss to property caused by natural disasters: competition or solidarity? World Competition 29(1):25-54.

Van Rijswick, H. F. M. W. 2014. Water en ruimtelijke ordening: wat brengt de toekomst? Pages 277-305 in R. C. J. Cremers, E. R. Hijmans, Y. Hinnen, A. M. Jansen, and W. H. E. Parlevliet, editors. Terecht Bouwrecht. Kluwer, Deventer, the Netherlands.

Vlaamse Milieumaatschappij (VMM). 2011. Globale evaluatie overstromingen 2010. VMM, Aalst, Belgium. [online] URL: $\underline{\text { http:// }}$ www.integraalwaterbeleid.be/nl/over-ciw/copy of evaluatieoverstromingen/Glob eval overstr nov2010 bijlage2-2.pdf 